\title{
MEASUREMENTS OF ACOUSTIC PROPERTIES OF HARD-PACK SNOW
}

\author{
By 'Theodore E. Lang \\ (Department of Civil Engineering and Engineering Mechanics, Montana State University, \\ Bozeman, Montana 597 I 5, U.S.A.)
}

\begin{abstract}
Aвsтkact. Three experiments were conducted to assess acoustic properties of hard-pack snow. One test involved transmission of acoustic signals in the frequency range $100-20000 \mathrm{~Hz}$ through natural snowpack in order to measure signal loss of a point acoustic source. At all frequencies the relatively high-energy input signal decays rapidly by energy dissipation, with nominal diffusion occurring at large distances from the source. Signal persistence is greatest in the frequency range $100-200 \mathrm{~Hz}$. In a second test, acoustic bursts in snow columns under deformation were recorded. Spectrum analysis in the frequency range $500-14000 \mathrm{~Hz}$ reveals dominance of signal amplitudes at frequencies between $\mathrm{I}$ ooo and 10 ooo $\mathrm{Hz}$. This dominance is attributed to the strong attenuation properties of snow and suggests the use of waveguide or collector techniques to monitor natural acoustic emissions in snow-pack. In a third test several waveguide geometries and materials were evaluated for their acoustic signal interception and transmission characteristics. In general, metallic waveguides show the least attenuation of the configurations tested.
\end{abstract}

RÉsumÉ. Mesures des propriétés acoustiques des plaques dures de neige. On a mené trois expériences pour déterminer les propriétés acoustiques de la neige en plaques dures. Un essai a consisté en la transmission de signaux acoustiques dans la gamme de fréquence 100 à $20000 \mathrm{~Hz}$ à travers un manteau neigeux naturel afin de mesurer la perte du signal à partir d'une source ponctuelle. A toutes les fréquences, l'énergie relativement forte du signal émis décroît rapidement par dissipation d'énergie avec une diffusion nominale atteignant de grandes distances de la source. La persistance du signal est maximum dans la gamme de fréquence de I 00 à $200 \mathrm{~Hz}$. Dans une seconde expérience, on a registré les crépitements dans des collonnes de neige en cours de déformation. L'analyse spectrale dans la gamme de fréquence de 500 à 14 ooo $\mathrm{Hz}$ a révélé la dominance des amplitudes des signaux à des fréquences de I 000 à $10000 \mathrm{~Hz}$. Cette dominance est attribuée aux fortes propriétés d'atténuation de la neige et suggère l'utilisation des techniques de guidage d'onde ou de collecteur pour canaliser les émissions acoustiques naturelles dans la neige. Dans une troisième expérience, plusieurs matériels et formes guides d'onde ont été comparés pour leurs caractéristiques de transmission et d'interception de signaux acoustiques. En général, les guides métalliques donnent l'atténuation minimale parmi les formes essayées.

Zusammenfassung. Messung akustischer Eigenschaften dichtgepackten Schnees. Zur Abschätzung akustischer Eigenschaften dichtgepackten Schnees wurden drei Versuche angestallt. Der erste bestand in der Durchleitung akustischer Signale im Frequenzbereich $100-20$ ooo $\mathrm{Hz}$ durch natürliche Schneedecken zur Messung der Signalabnahme punktförmiger Schallquellen. In allen Frequenzen schwindet das Signal trotz relativ hoher Eingangsenergie schnell durch Verschluckung der Energie; dabei tritt die Nenn-Diffusion weit entfernt von der Quelle ein. Im Frequenzbereich von $100-200 \mathrm{~Hz}$ wird das Signal am besten erhalten. In einem zweiten Versuch wurden akustische Explosionen in verformten Schneesäulen registriert. Die spektrale Analyse im Frequenzbereich 500-14 000 Hz ergab das Vorherrschen von Signalamplituden bei Frequenzen zwischen $\mathrm{I}$ ooo und г 0 ooo $\mathrm{Hz}$. Dieses Übergewicht wird den starken Dämpfungseigenschaften des Schnees zugeschrieben; es legt die Verwendung von Wellenführungs- und Kollektor-Verfahren zur Auffindung natürlicher Schallquellen in Schneedecken nahe. In einem dritten Versuch wurden verschiedene Wellenf ührungsgeometrien und -materialien auf ihre Charakteristiken der Aufnahme und Leitung akustischer Signale hin untersucht. Im allgemeinen zeigen metallische Wellenführer bei den verwendeten Konfigurationen die geringste Dämpfung.

\section{Introduction}

Acoustic-type pressure waves, generated through slip and fracture of the microstructure of a material under load, can be monitored electronically. In this relatively new field of study, a correlation between severity of loading and frequency of acoustic bursts has been established for numerous materials (Dunegan and Harris, 1969). The potential use of this natural mechanism to estimate snow avalanche criticality is currently under study. That snow under load generates acoustic emissions is known, (St. Lawrence and others, I973; St. Lawrence and Bradley, in press; Bradley and St. Lawrence, in press), and the follow-on. questions of technique and procedure in monitoring an avalanche-sensitive slope remain. To aid in designing an acoustic monitoring system for deployment on a snow slope, a number of correlating experiments have been conducted. Results are reported from three experimental programs, namely: (I) audio-signal decay in natural hard-pack snow slabs, (2) low-frequency 
acoustic emission spectra of snow columns under deformation, and (3) evaluation of waveguides for intercepting sound in snow. These experimental results provide order-of-magnitude estimates of the distance over which a signal generated in a snow-pack can be intercepted, the expected frequency range of intense acoustic emissions, and the relative merits of the use of mechanical devices to intercept acoustic signals in snow-pack.

\section{Audio-signal transmission in natural hard-Pack SNOW Slab}

This experiment to measure relative signal decay in natural snow slabs was conducted in the Bridger Mountain Range near Bozeman, Montana, at $2200 \mathrm{~m}$ elevation on midwinter snow-pack. Nominal snow weight per unit volume was $3000 \mathrm{~N} \mathrm{~m}^{-3}$ and average snow temperature varied between -2 and $-5^{\circ} \mathrm{C}$ over the three-week testing period. The work supplements that of Ishida ( 1965 ) who considered acoustic attenuation in snow blocks up to o. I $\mathrm{m}$ thick under controlled material and boundary conditions. Signal decay reported herein is over snow spans up to $4.0 \mathrm{~m}$ in natural snow-pack, for which neither material homogeneity nor boundary conditions were strongly controllable.

The test set-up consisted of a permanent-magnet induction speaker supported next to the side wall of a snow pit (Fig. I). An aluminum rod connected to the voice coil extended to a $5 \mathrm{~cm} \times 5 \mathrm{~cm}$ square aluminum plate which was implanted in the snow wall. Approximately $2.5 \mathrm{~cm}$ in front of the plate a contact microphone was embedded in the snow-pack with silica gel. An identical transducer was imbedded similarly at different field locations. Signals from the two transducers were amplified, filtered (pass band $100-100000 \mathrm{~Hz}$ ), and measured using a digital voltmeter. The $8 \mathrm{~W}$ speaker voice coil was driven sinusoidally over a frequency range 100 to $30000 \mathrm{~Hz}$ at approximately $75 \%$ saturation amplitude. The speaker and transducers were placed approximately $0.5 \mathrm{~m}$ below the snow surface in nominally $2.0 \mathrm{~m}$ deep snow.

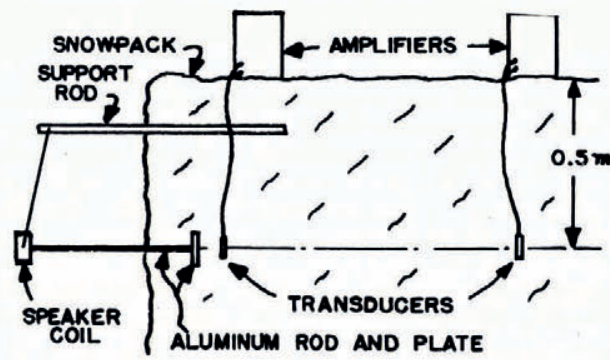

Fig. 1. Test set-up to measure audio-signal decay in snow-pack.

The testing sequence involved sweeping the frequency range for successive $1.0 \mathrm{~m}$ steps in the spacing between the fixed and the field transducers. To check configuration stability with time, the field transducer was returned to the $1.0 \mathrm{~m}$ and $2.0 \mathrm{~m}$ spacings occasionally, which accounts for the greater number of data points at these separations.

From the test set-up described it is apparent that signal decay involves mechanisms of attenuation as well as geometric signal spreading, or diffusion. For a line source normal to a plate of transmitting material, geometric diffusion amounts to $6 \mathrm{~dB}$ per doubling of radius, with any greater decay attributable to signal attenuation. In the results presented, lack of sufficient accuracy precludes definite separation of diffusion and attenuation components; however certain trends are significant. A summary of data points recorded and average signal-decay curves for sound transmission over distances of $1.0,2.0$ and $3.0 \mathrm{~m}$ are shown in Figure 2. At a transmission distance of $4.0 \mathrm{~m}$, no measurable sound was detected at any frequency, indicating signal decay in excess of $70 \mathrm{~dB}$. For signal frequencies greater than 
$3000 \mathrm{~Hz}$, signal decay is high, with significant decrement over $1.0 \mathrm{~m}$. The frequency range I $00-3000 \mathrm{~Hz}$ was divided into a number of sub-ranges, as listed in Table I, and average signal decays were computed using all data points in each sub-range. Nominal signal diffusion is in evidence between $1.0,2.0$ and $3.0 \mathrm{~m}$, with a trend toward signal attenuation at the higher frequencies. However, the dominant characteristic is the high signal loss between the source and $1.0 \mathrm{~m}$. This indicates that any attempt to induce high levels of acoustic or vibration excitation of snow results in large localized energy dissipation which is attributable to the non-linear viscous behavior of snow at high deformation rates. The conclusion from this is that any system for monitoring a snow slab acoustically using high-frequency signals must itself be distributed, as transmission from acoustic sources can be expected to be to a maximum of 1.0 to $3.0 \mathrm{~m}$. It is noted further from the data in Table I, that, at $3.0 \mathrm{~m}$, signals in the range $\mathrm{I}$ ooo- $3000 \mathrm{~Hz}$ have decayed to the threshold level (70 $\mathrm{dB}$ ), whereas signals in the range $\mathrm{I} 0 \mathrm{n}-200 \mathrm{~Hz}$ show greatest persistence.
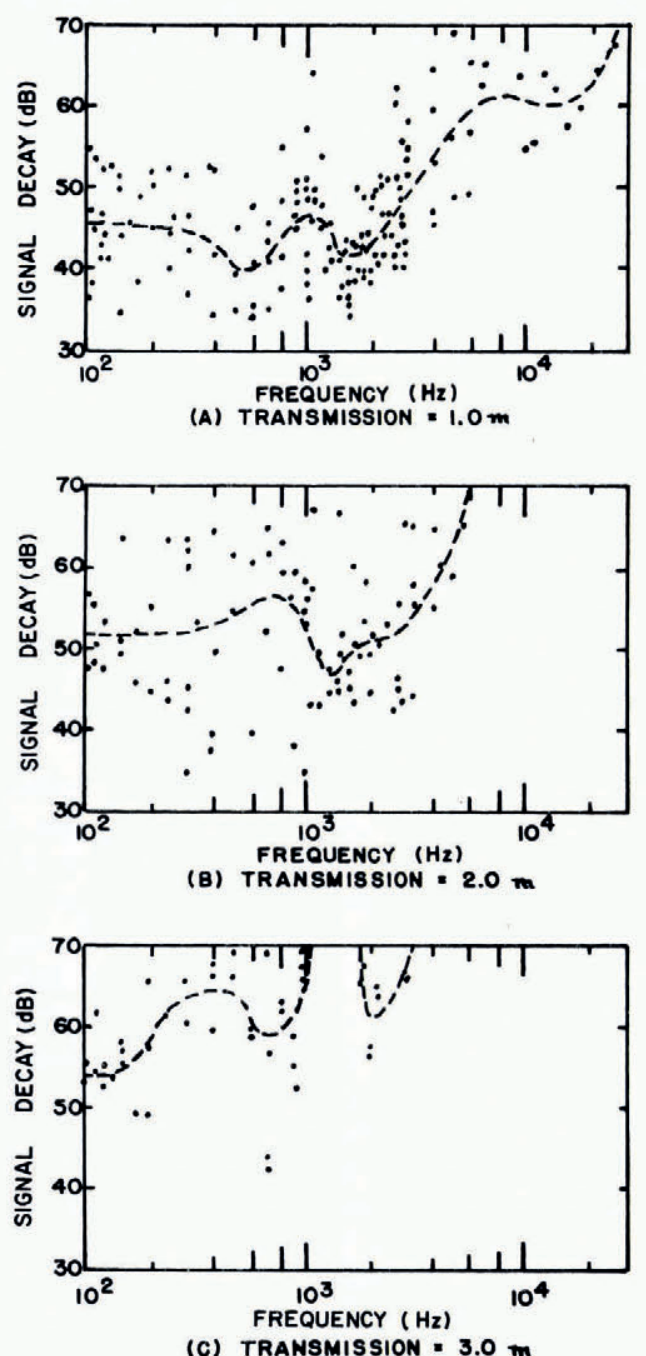

Fïg. 2. . Acoustic signal decal tersus frequency in snow-pack. 


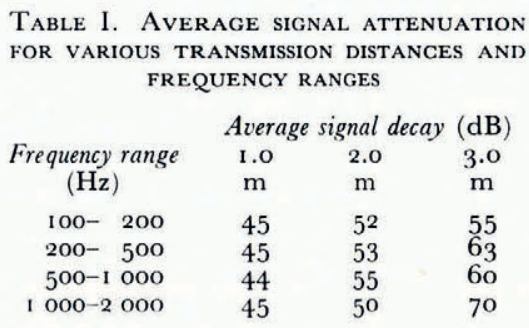

The large scatter of the data points of Figure I should be anticipated in acoustic field tests. Reception at the transducers is influenced by a number of factors including signal reflection from natural material layering and local material inhomogeneities, lack of reproducibility in implanting the transducers in silica gel in the snow-pack, and variations in material configurations between test sites. These reported results are for a particular snowpack with its attendant deposition and aging characteristics, averaged somewhat by the fact that the experiments were conducted at several locally spaced sites (within a $50 \mathrm{~m}$ radius). The omission of data in the frequency range $0-100 \mathrm{~Hz}$ is significant, and further experimentation is warranted.

\section{LOW-FREQUENCY ACOUSTIC EMISSION SPECTRA OF SNOW COLUMNS UNDER DEFORMATION}

Snow columns measuring nominally $7.0 \mathrm{~cm} \times 7.0 \mathrm{~cm} \times 20.0 \mathrm{~cm}$ were cut from a natural snow block of weight per unit volume $3300 \mathrm{~N} \mathrm{~m}^{-3}$, then frozen to the load platens of a standard Instron testing machine in $\mathrm{a}-5^{\circ} \mathrm{C}$ test chamber. The range of strain-rates imposed along the $20 \mathrm{~cm}$ axis were $0.0032-0.032 \mathrm{~min}^{-1}$ in compression, and $0.00027-0.0028 \mathrm{~min}^{-1}$ in tension, up to a $10 \%$ total strain. Sound pressures within the specimen caused by grain and grainboundary slip and fracture were monitored by a $P Z T$ transducer mounted on the side of the specimen and separated from it by a thin layer of silica gel. The signal from the transducer was amplified and recorded on magnetic tape. Because of noise from the testing machine, the useful frequency band was nominally 500-1 $4000 \mathrm{~Hz}$. Selected $4.0 \mathrm{~s}$ segments of the recorded tape were made into loops, and these data played into a $7 \mathrm{~Hz}$ spectrum analyzer with variable center-frequency band-pass and plotted. Background spectra were obtained from noise recordings of the complete system, including test specimen, with the testing machine running but not loading the test specimen. Separately, it was determined that engaging the testing machine drive generates additional low-frequency noise which has significant amplitudes only below the low-frequency cut-off $(500 \mathrm{~Hz})$ of the experiment.

Typical low-frequency spectra of acoustic bursts in snow in tension and compression are shown in Figures 3 and 4 . By overlaying the background and signal spectra, the dominant acoustic frequencies and amplitudes can be identified. Comparing the spectra of Figures 3 and 4 , it is seen that emissions in tension are stronger than emissions in compression, particularly when it is noted that the strain-rates differ by an order of magnitude. The spectra shown were taken during the time of initial rapid loading when emissions are frequent compared with activity during the secondary stage of loading. Acoustic activity also intensifies as strain-rates are increased, particularly at rates leading to brittle fracture in tension. If the frequency range from 500 to $14000 \mathrm{~Hz}$ is divided into $500 \mathrm{~Hz}$ increments, and the dominant emission amplitudes counted, the distribution of emission amplitudes in tension and compression are as shown in Figure 5. The concentration of counts is in the $\mathrm{I}$ ooo to $10 \mathrm{ooo} \mathrm{Hz}$ range. This is in evidence in Figure 5 where the amplitude-weighted-average frequency is a minimum of $30 \%$ less than the average frequency of amplitudes. 


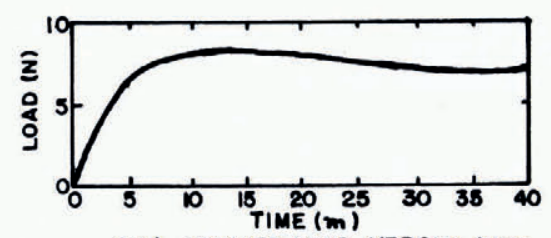

(A) APPLIED LOAD VERBUS TIME

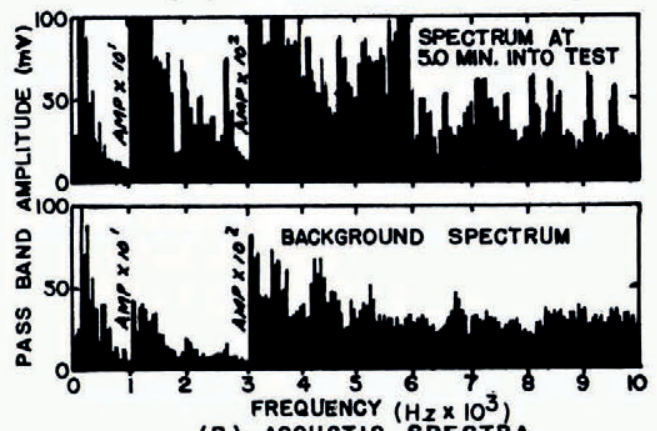

(B) ACOUSTIC SPECTRA

Fig. 3. Acoustic emission spectra and loading of a snowe column in immpression at a stain-1ate of o.oof 7 min $^{-1}$ (note that decade amplitude increases at certain /requencies

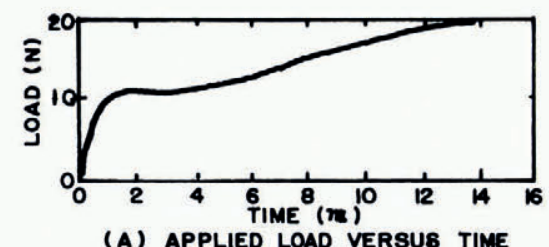

(A) APPLIED LOAD VERSUS TIME

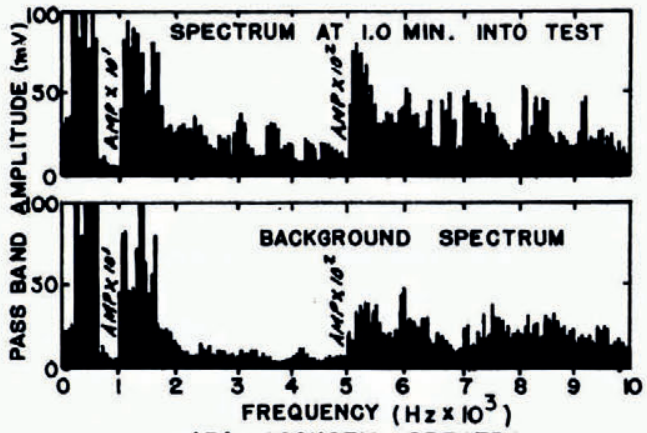

(B) ACOUSTIC SPECTRA

Fig. 4. Acoustic emission spectra and loading of a snow column in tension at a strain-rate of (1.oues fog min ${ }^{-1}$ (note that decade amplitude increases at certain frequencies).

It cannot be concluded from the results given that acoustic emission generation in snow is a low-frequency phenomenon. The rapid decay of high-frequency signals, as noted in Section II, means that the volume of snow column contributing to the high-frequency content at the transducer is smaller than the volume contributing to the low-frequency content. Thus, for adequate interception of sound sources in field applications of acoustic emission techniques, a collecting or waveguide concept may be needed. 


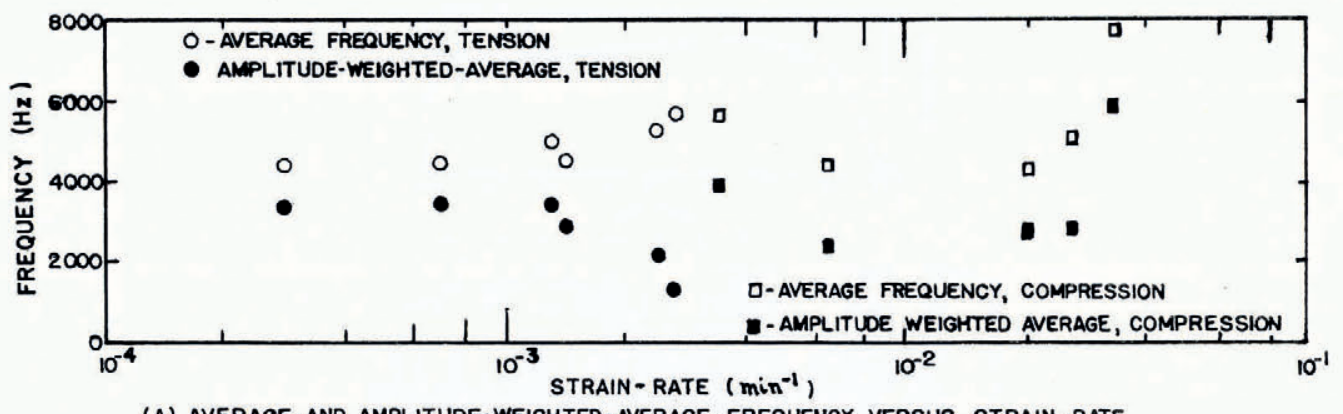

(A) AVERAGE AND AMPLITUDE-WEIGHTED-AVERAGE FREQUENCY VERSUS STRAIN-RATE

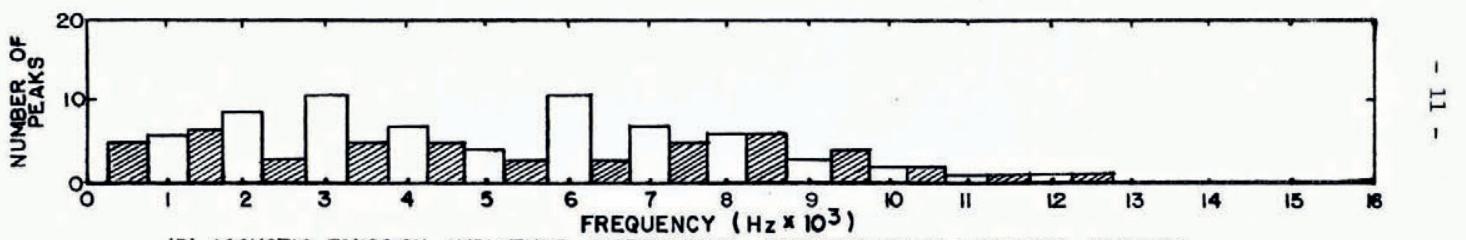

(B) ACOUSTIC EMISSION AMPLITUDE DISTRIBUTION, SUMMARY OF 12 TENSION SPECTRA

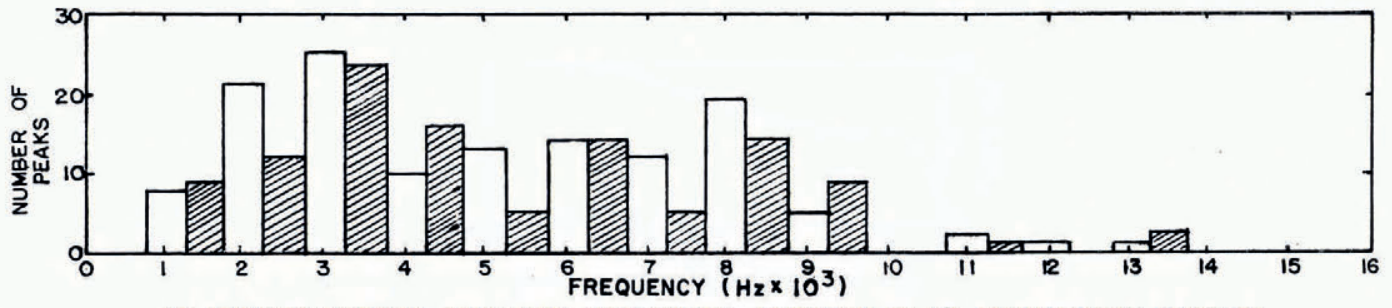

(C) ACOUSTIC EMISSION AMPLITUDE DISTRIBUTION, SUMMARY OF 23 COMPRESSION SPECTRA

Fïg. 5. Summary of frequency acerages and amplitude distributions of acoustic emissions in tension and compression.

\section{WAVEgUIDE EVALUATION FOR SOUND INTERGEPTION IN SNOW}

Several possible waveguide geometries and materials were tested in the laboratory to determine their sound interception and transmission characteristics. Waveguides were selected for ease of deployment on snow slopes, and minimization of expense in fabrication; thus, simple cross-sections were selected. Although the waveguide is intended to intercept acoustic bursts, a vibration source was used in the laboratory evaluation. Waveguide configurations tested, all $1.0 \mathrm{~m}$ in length, include the following:

(I) Steel rod: diameter $4.13 \mathrm{~mm}$.

(2) Steel plate, rigid: cross-section $6.0 \mathrm{~mm} \times 63.0 \mathrm{~mm}$.

(3) Steel plate, flexible: cross-section $0.81 \mathrm{~mm} \times 63.0 \mathrm{~mm}$.

(4) Steel sheet: cross-section $0.8 \mathrm{I} \mathrm{mm} \times 300 \mathrm{~mm}$.

(5) Steel rod with welded $90^{\circ}$ corner: diameter $4.13 \mathrm{~mm}$.

(6) Steel rod with $50 \mathrm{~mm}$ radius, $90^{\circ}$ bend: diameter $4.13 \mathrm{~mm}$.

(7) Steel wire mesh: wire spacing $8.5 \mathrm{~mm}$, wire diameter $0.8 \mathrm{I} \mathrm{mm}$.

(8) Wood plate: cross-section $6.0 \mathrm{~mm} \times 63.0 \mathrm{~mm}$.

(9) Ice plate: cross-section $15.0 \mathrm{~mm} \times 63.0 \mathrm{~mm}$. 
The individual waveguides were mounted at the center of a block of sifted and re-sintered snow of weight per unit volume $3000 \mathrm{~N} \mathrm{~m}^{-3}$ as shown in Figure 6. For all waveguides the surface temperature was above freezing (or wet surface) when emplaced, and loose snow was leveled at the mid-height interface before the block was re-assembled and allowed to set for $72 \mathrm{~h}$ at $-20^{\circ} \mathrm{C}$. A driving $P Z T$ transducer was mounted $0.2 \mathrm{~m}$ from one end of the waveguide with a separation of $0.14 \mathrm{~m}$ of snow from the waveguide surface. A similar monitoring transducer was mounted onto a small steel block, which in turn was either welded, glued or frozen to the waveguide. The driving transducer was excited from a signal generator and power supply, and the monitoring transducer output was measured with a digital voltmeter.

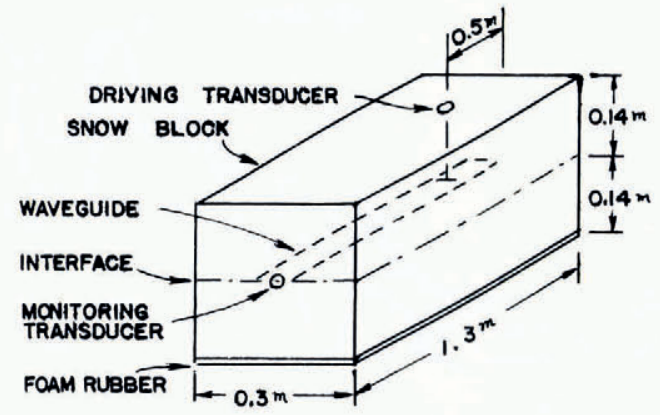

Fig. 6. Waveguide test configuration.

The intent of the evaluation is to compare the relative attenuation characteristics of the various waveguides. Thus, for each test, frequency and amplitude settings were made the same, and the frequency was, swept from 2.0 to $60 \mathrm{kHz}$ although not all waveguides responded over the entire range.

The curves of attenuation versus frequency of the various waveguides, having subtracted the experimentally measured attenuation of $0.14 \mathrm{~m}$ of the snow block from each, are shown in Figures 7 and 8 . The attenuation of the various steel waveguides, excepting the wire mesh, is

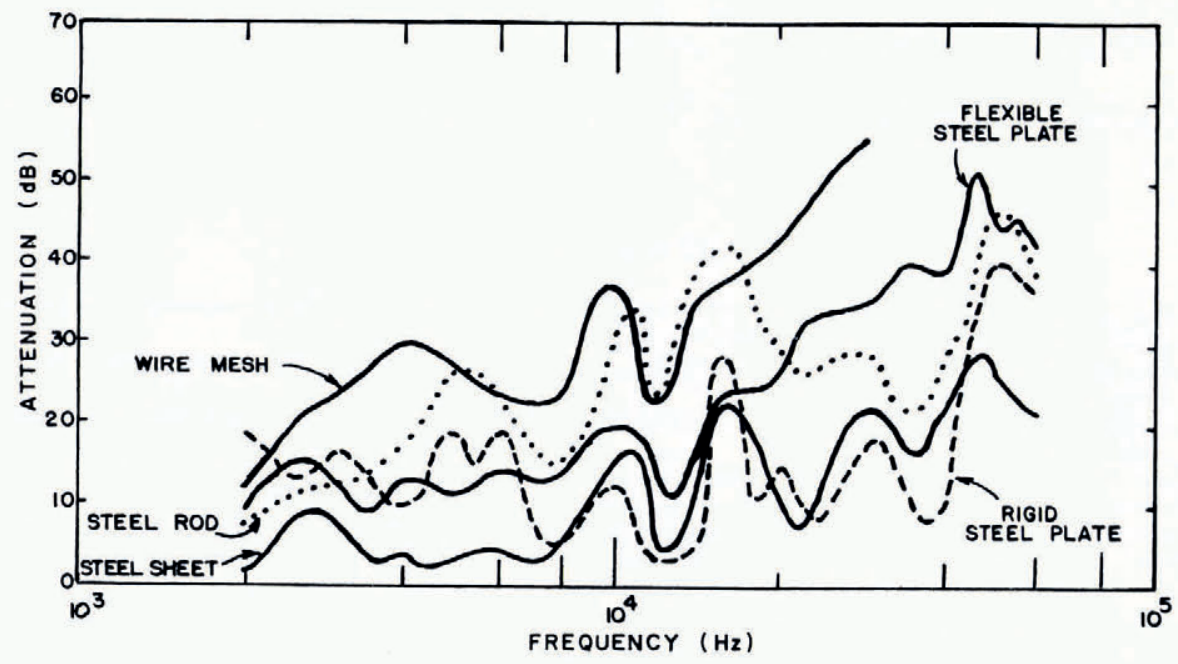

Fig. 7. Attemuation versus frequency of steel waveguides with different cross-sections. 
generally less than the wood and ice plates. The insertion of a sharp corner in a steel waveguide has a significant degrading effect on signal transmission, particularly at higher frequencies. The ice plate, which has the advantage of easy emplacement in remote sites, shows relatively high attenuation compared to the metallic types. A waveguide not tested, but which may have the greatest utility in monitoring snow-pack emissions, is the basal layer of rock. Testing of this configuration is most readily carried out by direct field measurements.

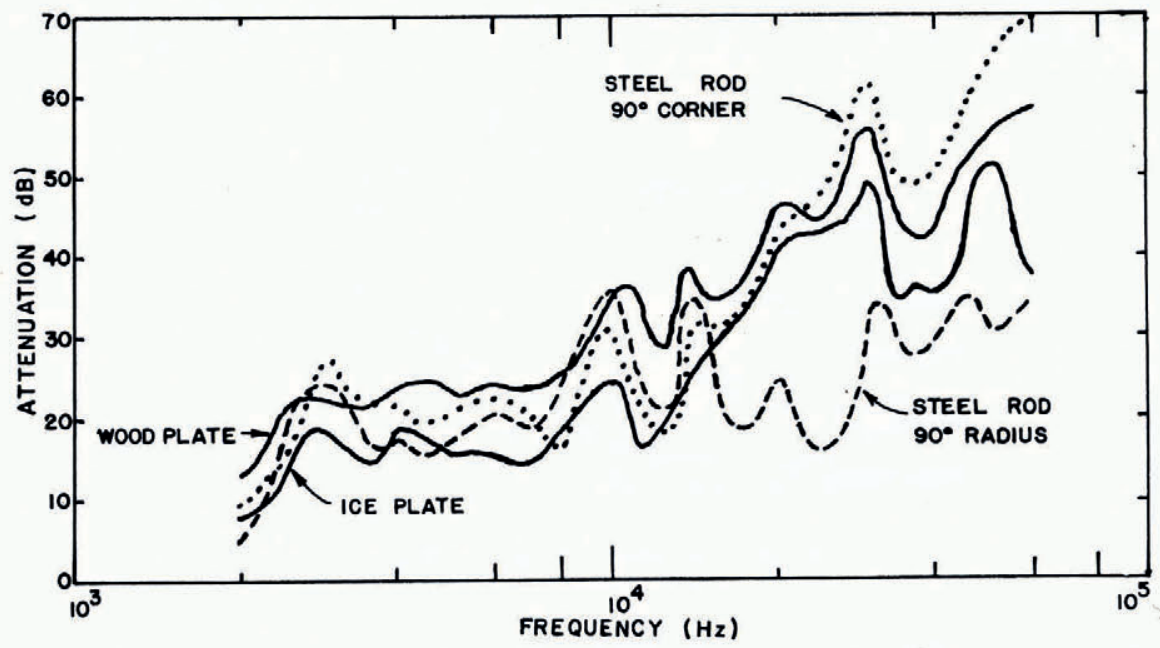

Fig. 8. Attenuation versus frequency of miscellaneous waveguide configurations.

\section{Acknowledgement}

The comments and criticisms by Dr Richard Sommerfeld and Mr William St. Lawrence during the course of this work are gratefully acknowledged. This work was supported by the National Science Foundation (Grant No. NSF GA-3943) and the Office of Army ResearchDurham (Grant No. DA-ARO-D-3 I-I 24-7I-G59).

MS. received I5 August 1975 and in revised form 13 October 1975

\section{REFERENCES}

Bradley, C. C., and St. Lawrence, W. F. In press. The Kaiser effect in snow. [Paper presented at International Symposium on Snow Mechanics, Grindelwald, 1974.]

Dunegan, H., and Harris, D. 1969. Acoustic emission-a new nondestructive testing tool. Ultrasonics, Vol. 7 , No. 3 , p. $160-66$.

Ishida, T. 1965. Acoustic properties of snow. Contributions from the Institute of Low Temperature Science (Sapporo), Ser. A, No. 20, p. 23-63.

St. Lawrence, W. F., and Bradley, C. C. In press. The deformation of snow in terms of a structural mechanism. [Paper presented at International Symposium on Snow Mechanics, Grindelwald, 1974.]

St. Lawrence, W. F., and others. 1973. Acoustic emission in snow at constant rates of deformation, by W. F. St. Lawrence, T. E. Lang, R. L. Brown and C. C. Bradley. Journal of Glaciology, Vol. i 2, No. 64, p. $144-46$. 